Vol. 2, nº 1 | 1998

Varia

\title{
Crime and History - the German Workshop
}

« Historische Kriminalitätsforschung in der Vormoderne » / « Early Modern Crime and Criminal Justice History "

Andras Blauert and Gerd Schwerhoff

\section{CpenEdition}

1 Journals

Electronic version

URL: https://journals.openedition.org/chs/1003

DOI: $10.4000 /$ chs.1003

ISSN: 1663-4837

Publisher

Librairie Droz

Printed version

Date of publication: 1 January 1998

Number of pages: 137-140

ISBN: 2-600-00279-0

ISSN: 1422-0857

Electronic reference

Andras Blauert and Gerd Schwerhoff, "Crime and History - the German Workshop", Crime, Histoire \& Sociétés / Crime, History \& Societies [Online], Vol. 2, n¹ | 1998, Online since 03 April 2009, connection on 24 March 2022. URL: http://journals.openedition.org/chs/1003; DOI: https://doi.org/10.4000/chs 1003 


\title{
Crime and History - the German Workshop «Historische Kriminalitätsforschung in der Vormoderne» «Early Modern Crime and Criminal Justice History»
}

\author{
Andras Blavert \\ Gerd Schwerhoff
}

$\Delta s$ in other Western European countries, although with some delay, Crime A and Criminal Justice History has become a distinctive sub-discipline of social history in Germany in the last few years. The first impulsion came from historical research on lower social strata and marginal groups, but also from the investigation of social unrest. This area soared in the seventies and eighties. A large number of scholars working in the field of crime and criminal justice history in Germany came to the subject « via » their research in previous years on witchcraft and witch trials. This group attained "critical mass " in the early nineties, when some 20 scholars, mainly from the field of history and neighbouring disciplines, met for the first time to exchange ideas and experiences.

The German researchers in this field work in the history of deviant and criminal behaviour, on the one hand, and in the history of penal legislation and criminal justice procedures, on the other, as well as in the institutional development of the police and judicial apparatus. In a middle-range perspective, the emergence and engineering of varying mechanisms of social control were also a major point of interest. It is probably due to the already-mentioned 'lag' of German historiography in the area of crime and criminal justice, that its development differs from that in other countries. Whereas the historiographies of other countries started with a stronger emphasis on quantitative methods and on statistics as sources - at least in comparison with the German situation -, this group is more sceptical as to the analytical force and reliability of statistics. In their local and regional case-studies, the investigation of various forms of deviant behaviour is, above all, used as an access to the ways of life of the past. Only a small number of the German researchers makes extensive use of quantitative methods, and almost no-one employs this methodological instrument without simultaneously working qualitatively, without combining analytical and hermeneutical accesses to the topic. Thus, the German history of crime is strongly influenced by the methodological and theoretical discussions of historical anthropology and micro-history and it also attempts to participate in these discussions. In the source material of crime and criminal justice history research, which comes from the desks of public offices, the historical subjects do not speak directly, and this fact guarantees that the link to more classical questions of social history - like, for instance, those of the distribution of power and influence in societies, or, more 
specifically, between the authorities and the subjects - remains on the agenda of German crime and criminal justice history.

In recent years, German crime and criminal justice history has concentrated on the following themes: Apart from the classical types of criminal offences like murder, robbery, and theft, petty crimes like insults or transgressions of common decency are intensively inquired into. Under the influence of gender history, the interest in female- or male-specific crimes has increased as much as the interest in matrimonial and other disputes between the sexes. Finally, many historians - not least thanks to the background paradigm of «confessionalization »-have turned to a more intensive concern with the church courts and the disciplining or penalisation of sinfulness («Sündenzucht»). Thus, the interests are manifold; their common denominator may be best seized by the concept and term «history of conflicts».

The first exchange of ideas and opinions has turned into a regular institution : for the last seven years, the work-shop for Historical Crime Research has represented a communication forum for a growing number of predominantly younger researchers. The annual meetings in Stuttgart-Hohenheim (under the aegis of the « Katholische Akademie der Diözese Rottenburg-Stuttgart») bring together scholars from history, legal history and ethnology. Especially since the creativity is not confined by any strictly limited topic or any obligation to publish, new themes and theses can be freely presented for discussion. A glance at the reports and lectures given these meetings reveals the main foci of the German crime and criminal justice history, the time periods covered, the topics, and the methods applied. Chronologically, the emphasis clearly rests on the late middle ages and, above all, the early modern period, while topics from the early and high middle ages or from the nineteenth and twentieth centuries are almost completely absent. Regarding the topics, the emphasis naturally falls on studies of single offences or societal fields of conflict (for instance, gang crimes, violence, blasphemy, poaching, murder, etc.), but above all on studies which try to deal with their subject in a differentiated manner - be it for gender-specific aspects of deviance and criminality, or questions related to individual criminals and their experiences («criminal » biographies), or the distinction between strategies of disciplining and denominationalization deriving from the state or the church. Of course, more fundamental, theoretical or methodical reflexions are also presented. In particular, speakers have reported on the following topics:

\section{Historical Crime Research in the Early Modern Period (6-8 July 1991)}

Susanna Burghartz (Basel): Kriminalitätsgeschichte und Gesellschaftsgeschichte - einige methodische Überlegungen; Silke Göttsch (Kiel): Altes Recht und Gewohnheit. $Z$ u den (Un-)Rechtsvorstellungen leibeigener Untertanen im 18. Jahrhundert in Schleswig-Holstein; Heinrich R. Schmidt (Bern): Reformierte Sittengeschichte. Ziele und Methoden ihrer Erforschung; Helga Schnabel-Schüle (Tübingen): Rechtsgeschichte und Sozialgeschichte. Zurnotwendigen Verbindung zweier historischer Disziplinen; Gerd Schwerhoff (Bielefeld): Historische Kriminalitätsgeschichte im Aufbruch; Otto Ulbricht (Kiel): Jüdische Bandenkriminalität im 18. Jahrhundert.

\section{Deviant Behaviour - Social Control - Every day Behaviour} (12-14 June 1992)

Andreas Blauert (Konstanz): Kriminaljustiz und Sittenreform im Hochstift Speyer im 16. und 17. Jahrhundert; Michael Frank (Bielefeld): "Weil die Ordnung 
die Seele aller Dinge ist». Dörfliche Gesellschaft und Kriminalität - das Fallbeispiel Lippe (1650-1800); Ulrike Gleixner (Berlin): Die Konstruktion von Geschlecht. Zur Funktion von Unzuchtsprotokollen im 18. Jahrhundert in Preußen (Altmark 1700-1750); Valentin Groebner (Basel): Gewalt im Spätmittelalter nach Nürnberger Schadensverzeichnissen; André Holenstein (Bern): Kriminalität und Strafen im Bern des 16. Jahrhunderts; Frank Konersmann (Bielefeld): Normen, Verfahren und Instrumentarien protestantischer Ehegerichtsbarkeit im Herzogtum Pfalz-Zweibrücken; Gerd Schwerhoff (Bielefeld): Blasphemie - erste Überlegungen zur dunklen Seite des Mittelalters; Peter Wettmann-Jungblut (Saarbrücken): Die Überlebenslügen der Ursula Hollenstein: Zum Problem von Fiktion und Faktizität in einer «kriminellen» Biographie um 1800.

\section{III. (Un-) Written Laws: Setting, Realizing and Disputing Norms (10-12 June 1993)}

Renate Dürr (Stuttgart): Mägde in Unzuchtsverfahren in Schwäbisch Hall (17. Jahrhundert); Winfried Freitag (München): Wildererbanden in den Forsten um München am Ende des 17. Jahrhunderts; Silke Göttsch (Freiburg/ Kiel): Mord in der Wahrnehmung der ländlichen Gesellschaft im 18. Jahrhundert; Klaus Graf (Koblenz): "Das leckt die Kuh nicht ab.» Gedanken zur Schriftlichkeit der Strafgerichtsbarkeit (14.-16. Jahrhundert); Monika Mommertz (Berlin): «...hat ermeldtes wai mich angefallen...» Frauen und Herrschaft in Rechtsanfragen an den Brandenburger Schöppenstuhl um 1600; Heike Talkenberger (Stade): Zwischen bürgerlicher Existenz und Außenseitertum. Normenkonflikte in der Autobiographie des Luer Meyer (1850).

\section{Individual Biographies and Social Control (30 June-2 July 1994)}

Michael Frank (Bielefeld): Konflikte um Selbstmörder. Suizid und Gesellschaft in der Grafschaft Lippe (1600-1800); Michaela Hohkamp (Göttingen): «Niemand hat vernünftig muethmassen können, daß sie einen anstandt $z u$ der Ehe finden werde."Zum Lebensentwurf einer blinden Frau in einer ländlichen Gesellschaft des 18. Jahrhunderts; Sabine Kienitz (Tübingen): Geschäfte mit dem Körper. Sexualmoral und Überlebensstrategien von Unterschichtfrauen Anfang des 19. Jahrhunderts in Württemberg; Jutta Nowosadtko (Essen): Gehängte Henker oder sozialdisziplinierte Angestellte? Bayerische Scharfrichter als Objekte des Strafvollzuges; Herbert Reinke (Berlin/Köln): Internationalität und Interdisziplinarität in der historisch-kriminologischen Forschung. Eine Übersicht über Vereinigungen, Institutionen und Fördermöglichkeiten im Forschungsfeld; Peter Wettmann-Jungblut (Saarbrücken): Der Ruin unserer Haushaltung. Unmoralische Liebe, öffentliche Moral und das «Band unserer Haushaltung" in einer Freiburger Baderfamilie des 18. Jahrhunderts.

\section{Social Control - Employing the Judicial System - Strategies in Court (4-6 May 1995)}

Martin Dinges (Stuttgart): Soziale Kontrolle - Justiznutzung - Strategien vor Gericht. Thesen zur Kriminalitätsgeschichte; Joachim Eibach (Gießen): Streithändel. Ehr- und Körperverletzungen in Frankfurt im 18. Jahrhundert; Otto Feldbauer and David Lederer (München): Der Januskopf der Gerechtigkeit. Frauen, Geistliche und Konkubinatsverfahren nach dem Tridentinum; Winfried Freitag (München): Historis- 
mus als moderne Sozialgeschichtsschreibung? Zu Gerhard Oestreichs Konzept der Sozialdisziplinierung; Dorothea Nolde (Hamburg): «Er hatte keine Feinde außer ihr». Gattenmord im Frankreich des 16. Jahrhundert; Ulinka Rublack (Cambridge): Untertanen, Amtmänner und Herrschaftspraxis im frühneuzeitlichen Württemberg; Peter Schuster (Bielefeld): Strafverfolgung in Konstanz im 15. Jahrhundert.

\section{Intra- and Extrajudicial Settlements of Conflicts (2-4 May 1997)}

Karl Härter (Frankfurt a. Main): Inquisitionsprozeß, außergerichtliche Verwaltungsverfahren und Supplikationswesen in Kurmainz; Carl A. Hoffmann (München): Außergerichtliche Einigungen im Anschluß an Strafverfahren des 16. Jahrhunderts am Beispiel Augsburg; André Holenstein (Bern): Frevelgerichte in Baden im 18. Jahrhundert. Zum Funktionswandel einer gerichtlichen Institution; Barbara KrugRichter (Münster/Potsdam): Rechtsfindung zwischen dörflicher Sozialkontrolle und patrimonialer Gerichtsbarkeit. Das Rügegericht in der westfälischen Herrschaft Canstein 1718/19; Francisca Loetz (Heidelberg): Religion vor Gericht. Gotteslästerungen in Stadt und Landschaft Zürich ca. 1500-1800; Erika Münster (Ratingen): «Einem jederen unpartheyisch Recht wiederfahren lassen.» Strafjustiz, Untertan und Obrigkeit im Herzogtum Jülich in der ersten Halfte des 16. Jahrhunderts.

\section{Seftlement and Intensification of Conflicts (24-26 April 1997)}

Ralf-Peter Fuchs (München) : «Gott läßt sich nicht verspotten.» Zeugen im Parteienkampf vor frühneuzeitlichen Gerichten; Gudrun Gersmann (München): Denunziationen vor der Pariser Polizei im 18. Jahrhundert; Peter Arnold Heuser (Bonn): Blutgerichtsbarkeit in einem geistlichen Flächenstaat der frühen Neuzeit. Das Kurfürstentum Köln im 16./17. Jahrhundert; Frank Konersmann (Bielefeld): Strafgerichtsbarkeit in der Residenzstadt Zweibrücken im 18. Jahrhundert; Christoph Motsch (Berlin): Ausgehandelte Herrschaft. Interessenaustragung zwischen Pfandherr und Untertanen in der Starostei Draheim im 17. und 18. Jahrhundert; Christine Schedensack (Münster): Konfliktlösungsstrategien in institutionalisierten nachbarrechtlichen Auseinandersetzungen am Beispiel münsterscher Prozeßakten; Gabriela Signori (Bielefeld): Das ungleiche Paar. Über die schwankhaften Züge spätmittelalterlicher Gerichtsfälle.

A compilation of essays of the German history of crime is going to be published in 1998 at the Universitätsverlag Konstanz.

Priv.Doz. Andreas Blauert

Friedrich-Schiller-Universität Jena

Juristische Fakultät

O7740 JENA (FRG)

Priv.Doz. Gerd Schwerhoff

Universität Bielefeld

Fakultät für Geschichtswissenschaft

und Philosophie

Postfach 100131

33501 BIELEFELD (FRG)

(gschwerh@geschichte.uni-bielefeld.de) 